\title{
Name-giving variations in Kurdistan Province of Iran: An ethnic identity marker categorized
}

\author{
Abbas Eslami-Rasekh \\ University of Isfahan, Iran
}

Mohammad Ahmadvand

University of Isfahan, Iran

\section{Introduction}

Causes such as international trade and ease of transportation have resulted in the emergence of globalization. The effects of our modern time developments have increased the capacity for international interaction across cultures (Wang \& Le, 2006). The outcome of globalization contributes to advancements in intercultural communication studies (Penbek, Yurdakul, \& Cerit, 2009). Today, the world is considered as a village in which coping with differences is a major motive for speakers, a phenomenon referred to as conforming. Differences in values, attitudes, ethnicity, social practices, religion, etc. exist and need to be observed and valued with respect. Speakers need the ability to adapt their attitude towards foreign interlocutors by being flexible. It is a critical necessity for one to survive in the globalized world of this century. Individuals negotiate, realize, or even reject identities through speech which is used for expressing identity in a more significant degree than using such cultural artifacts as dress, food, housing, etc. (Wardhaugh, 2006). Our knowledge of the world and our experience of social realities influence our interpretations in general; even the use of personal pronouns might be an indicator of identity (Bloor and Bloor, 2007). Human experience is in close contact to language which is a window through which one observes the world which is spoken of (Johnstone, 2008).

A name is a person's possession and marks the identity of the holder revealing to others among several messages, who the holder is through reference (Mayrand, 2011). An important manifestation of language is presented in naming preferences. Personal first names not only function as common devices for direct reference to addressees in a private informal manner but also function as abstract linguistic markers that signal the addressee's individuality (Jeshion, 2009). Personal names include a major category of referring expressions and exist in languages forming a grammatical category named nouns and occupy a major section among the vocabulary of languages; like any other nominals, they follow the phonological, morphological, syntactic, and semantic norms and rules in their structure and use. 
Abbas Eslami-Rasekh, Mohammad Ahmadvand

Names as one category of referring expressions carry both a meaning as well as values, traditions, hopes, fears, and everyday events in people's lives. They reveal the preferences and concerns of both name holders and name givers in terms of a) real life objects, b) actions, and c) beliefs of an ethnic group (Rosenhouse, 2002).

A name, known to speakers as first name, forename, Christian name etc, is a means of referring to persons; it differentiates between members of a family or a society in a narrower sense than last names which identify tribes and people related by blood, and are considered to be the inheritance of individuals from ancestors. A first name is purposefully given to a child by parents, grandparents, godfathers, local clergymen, etc. before or after the birth, unlike the family name which is a predetermined reference device necessary for official addressing in the sense that a group of individuals, regardless of sex, carry a common family name but have each different first names in which choice parents have a say and vary across different genders. Given names occur before the family name in most cultures; in contrast, it occurs after the family name in Hungary, parts of Africa, and most of the East Asia (e.g. China, Japan, Korea, and Vietnam). It is normal in some societies for an individual to have more than one forename; although the holder will permanently be identified by one which is most preferred by the holder and the surrounding society related to him.

The fact that choice of a name conveys the name holder's sense of identity and can potentially affect feelings for as long as a lifetime, one can clearly observe its sociolinguistic significance which makes it an important topic of research (Wikipedia, 2011; Aden, 2014). The influence of names put on persons is pervasive and can culturally be a good as opposed to a bad effect. While for the choice of last name there is very little chance of the holder to change if not happy with the one officially recorded, the choice of first name is within the domain of the parents' preferences. The importance of research on name giving is the fact that first names carry cultural information showing the incentive of the giver for unity with the people whose identity differs from them. In Iran, choice of a name reveals important facts about how Kurdish people view their ethnic identity in relation to other ethnicities in the country. The work presented here is an attempt to examine how Kurdish ethnic community in Iran demonstrate their conformity with other ethnic and sectarian Iranians. This study aims at answering the following research questions: 1- What socio-cultural factors underlie name giving in Kurdistan Province of Iran?, 2- Is there any difference in the names of men and women in Kurdistan?, and 3- Is there any change in or difference between naming practices of old and new generations in Kurdistan?

\subsection{The Sources of Personal Names}

Naming is an important act in any culture or any country. A child may be named after somebody or after a special event; names may remind parents of the pats and 
of precious things (Djcnonyomaye, 2002). Given names may be derived from the following sources:

* Aspiring personal traits whether external/internal, or physical/spiritual (e.g. Hoozān $=$ knowledgeable)

* Occupations (e.g. Varzegar $=$ farmer)

* Day or moment or circumstances of birth (e.g. Belāta $=$ the time for the blossoming of trees)

* Objects around, especially if they have important roles in people's lives (e.g. Parchin $=$ fence $)$

* Variations on another name, for instance, by adding a suffix to a male name to make it female (e.g. Sāheb is the male name and Sāheba is the female name = the owner)

* Geographical places (e.g. Deyānā $=$ the name of a village near Iraq border)

* Names of important people whether religious or divine, political, fictional, artistic, etc. (e.g. Kurdya $=$ the sister of Bahram Choobineh, an Iranian king)

* Names of ancestors or patronymic names (e.g. Kurdān = a king of the Madz Dynasty)

* Names based on cultural or ethnic concepts (e.g. Kurdoo = you Kurdish man)

* Names based on nature, animals, even agricultural environment and weather (e.g. Tondar $=$ thunder $)$

* Brands and innovation names, for example, Tahsin which is a new name for Kurdish boys (Wikipedia, 2011; Djcnonyomaye, 2002; Encyclopedia of Children, 2011; Myrand, 2011; Conrad, 2011; Ghaleb Al-Zumor, 2009).

\subsection{The Significance of Studying Personal Names}

Personal naming practices offer important insights and act as a key indicator of the patterns of social and cultural organization of communities. They give us important information about the sex and the social group of the infant and some hints about the name-giver; they may reveal significant information about the background and the circumstances at the time of the birth of a child. Names have a great symbolic power because they are chosen consciously; they will identify a person and may send a message to others regarding people's hopes, prayers, cultural traditions, religious inclinations, etc. (Alford, 1987). Names are not superficial phenomena, but clear expressions of cultural identity which is deeply imbedded in sociocultural contexts (Encyclopedia of Children, 2011). A name given to a child serves as a marker of identity both for the child and others living around a child (Gerhards \& Hans, 2009). Identity is based on implicit shared conventions considered and adhered to by people; these conventions make the internal functioning of a culture possible. Knowledge of naming practices can help us trace our families back to a village, or tell us about their occupation (Myrand, 2011).

A historical survey on names can help us access the past because names are reflections of everyday life, of world views, and of people's relationship within the family and beyond; they have an integrative function, integrating the new baby into 
Abbas Eslami-Rasekh, Mohammad Ahmadvand

the family organization or the community he will grow up in (Encyclopedia of Children, 2011). Gudrun (2002) maintains that most Icelandic personal names are of Nordic origin found in sagas, with some names traced back to the Christianization of the country in the year 1000. There are many labels for identity, for example, type of housing, clothes, the way we talk, our car, etc. but names are chosen freely and without any material cost in terms of money, time, or effort invested, so they are pure expressions of parents' preferences and ideas (Liberson, 2000).

Lexemes found in personal names show the values and ideas of the society concerned, and reveal details about people's life, details such as origins, professions, traditions, fashion, social rank, etc (Ghaleb Al-Zumor, 2009). Toppe (2011) reported that almost $70 \%$ of the Norwegian population have names related to farms. Bryner (2010) believes that the spread of unusual names these days shows the parents' overall philosophy that their child is special, that having a unique name helps the child stand out, that fitting into social norms is a bad thing, that names can lead to desired personality traits. The fact that in Christian countries 'Jesus' is not used for boys but 'Mary' is used for girls shows that Jesus is considered taboo or sacrilegious in parts of the Christian world (Wikipedia, 2011). In Lithuania (Girvilas, 1978) people believe that giving a name to an infant determines his/her fate.

The names of people even determines their future practices such as marriage. Medlej (2011) reports that in Burma the initial of names is determined by the day on which a baby is born; some days are incompatible with each other, so people born on these days cannot get married and, for example, you can't find a Khusband with an H-wife. A similar case was also reported in Korea; Koreans avoid marrying people who have the same family name and, for example, marriage between the Kims and the Parks _two very common last names in Korea_ is problematic. It is also interesting that theophorous names, i.e. names which refer to divine people are usually reserved for men in Judaism, for women in Christianity, and for both in Islam. Naming a child after godparents also reveals information about social relations and the form of organizations in a society; through godparent patronage new social relationships, alliances, and networks are created or reinforced (Encyclopedia of Children, 2011). Gardner (1988) reports that in Arab countries traditional or old-fashioned names refer to virtues of piety, justice, abundance, and purity, enduring names _names which have retained their popularity_ are associated with companionship and kindness, and new names depict concepts of love, happiness, and hope. Sue and Telles (2007) argue that ethnic names are more frequently used for male babies because they are expected to carry on family and ethnic traditions. In 1830 s to 1840 s in France, priests gave the name Philomene _after Saint Philomena who was associated with virginity_ to illegitimate girls, thereby marking their status (Encyclopedia of Children, 2011).

1.3. The Significance of Studying Changes in name-giving 
An important aspect of studying names is changes in the name-giving practices of communities. Gerhrads and Hasan (2009) offer four scenarios for changes in namegiving: 1) Forced acculturation, for example, when the Bulgarian government forced the Turkish minority to adopt Slavic names in 1986, or when the Turkish constitution in Turkey forbade the use of Kurdish language from 1983 to 2000 which also banned the registration of Kurdish names, 2) Forced segregation, for example, when in 1938 Jews were limited to Jewish names only and that all Jewish men and women with German first names had to add 'Israel' and 'Sara' to their names respectively, 3) Voluntary acculturation, when ethnic groups voluntarily give up their traditional first names and adopt names of the dominant ethnic group without any force by governments, and 4) Voluntary ethnic segregation or maintenance, for example, when, after the French Revolution of 1789, people had a return to names derived from the ancient Roman tradition.

Convergence into or divergence from other groups may result from spatial segregation, economic or occupational segregation, social segregation, acculturation, willingness for integration, etc. These changes are reflected in musical taste, dress, religion, recreational patterns, and name-giving practices (Gordon, 1964). Interesting cases have been reported on the reasons of changes in names. Nowadays, people like to name their children after figures from novels, opera heroes, actors and actresses, musicians, singers, athletes, etc. In 2004, the names 'Keira' and 'Kiera' gained popularity in Uk, following the rise in popularity of the British actress 'Keira Knightley'. After the release of the Beatles's song named "Hey Jude", there was an increase in the frequency of the name 'Jude' chosen for children. Similarly, after the popularity of the film 'Home Alone', there appeared a significant interest in the usage of the name 'Kevin', the main character of the film (Wikipedia, 2011.; Encyclopedia of Children, 2011). In Iran, the name "Abolfazl" was among the first three top names during the years 2005 to 2009 because of the world champion in wrestling 'Hoseyn Rezazadeh' who shouted the name when lifting the weights and the popularity he had in the Iranian society (Shabet Magazine, 2010). After the civil war in America, African Americans chose prohibited names like Moses and Abraham and used the complete names (e.g. Thomas) instead of shortened names (e.g. Tom) and names which showed their African roots (Conrad, 2011). A study by Aouda and Shousha (1991) showed a change in Arab names from religious names towards neutral names or shared values like hope, love, and happiness.

Gardner (1992, and 1993) argues that regarding change and new names, girls outnumber boys because boys are supposed to continue the traditions and the good family name whereas girls are given new names to enhance their attractiveness and to suggest change for a better future; there are also certain Hadiths (sayings of the Prophet Mohammad and Imams) and Quranic verses which include recommendations regarding choosing names for boys, and not girls. The popularity of the 
Abbas Eslami-Rasekh, Mohammad Ahmadvand

Egyptian soap opera singers is another reason mentioned by Gardner (1994) for the emergence of new names in the Arab world.

Personal names exist in all languages; they change, develop, and die. The study of name-giving and changes in name-giving reveals interesting patterns in a community's culture and changes in these patterns documenting the presence of a certain spirit during a certain time behind individuals' choice of names (Bryner, 2010; Ghaleb Al-Zumor, 2009).

\section{This Study}

Research Questions

This study aims at answering the following questions:

1- What socio-cultural factors underlie name giving in Kurdistan Province of Iran?

2- Is there any difference in the names of men and women in Kurdistan?

3 - Is there any change in or difference between naming practices of old and new generations in Kurdistan?

\section{Method}

\subsection{Materials}

The data for this study was collected from various sources including a questionnaire, Kurdish websites, Kurdish books on names and their origins, data bases of two institutes one of which was for people under 25 , and the other for people over 60 , and the National Organization for Civil Registration of Iran, and some interviews.

\subsection{Instrument}

At first data available (10000 collected tokens) was analyzed and 2346 names with only one occurrence in the corpus were identified. Consulting Kurdish people and books on the meaning and etymology of names, these names were traced back and classified into 10 groups. Then the frequency of these names was calculated. The names in each category were also divided into male and female names to see if there is any difference between naming patterns for men and women in the area. For the third part of the study a questionnaire was given to 50 Kurdistani residents in which they were asked to write down the names of their Kurdistani relatives, friends, and neighbours in four separate columns: men and boys under 25, men over 60 , women and girls under 25 , and women over 60 . The data collected (2224 tokens) was analyzed to see if there is any change in the names of older and younger generations. Also some informal interviews were held by the researchers to know about Kurdistani people's preferences for selecting a name. 


\subsection{Hypotheses}

1- The socio-cultural background of Kurdistani people underlies their naming practices.

2- There are significant differences between male and female names in the Kurdistan.

3- There are differences in naming patterns of older and younger generations in Kurdistan.

\section{Data Analysis and Interpretation of Results}

\subsection{A brief look at Kurdistan}

The Kurdistan Province of Iran $(28203 \mathrm{Km} 2)$ is located in the west of Iran. It has borders with West Azarbāyjān Province (mostly Kurdish and Turkish speaking) and Zanjān (Turkish speaking) from the north, with Zanjān and Hamedān (mostly Farsi and Turkish speaking) from the east, with Kermānshāh (mostly Kurdish speaking) from the south, and with Iraq (mostly Kurdish speaking areas) from the west. Kurdistan is surrounded by mountains. Two main rivers including Ghezelozon and Sirvān flow in the area. It is under the influence of two main (cold and warm) weather currents which cause a great diversity in the climate of the region. The variety of plants and natural landscapes has turned it into an interesting tourist resort, especially in spring and summer. The most important difference between people of Kurdistan and other Kurdish speaking provinces is that majority of the people are Sunni Muslims while the official religion in Iran is Shi'ite Islam. Kurds which or originally Aryans; once in Iran there were three races: Pars, the Madz, and Kurdan. Kurds are proud of their ethnicity and manifest their ethnic identity not only by speaking Kurdish but also by their appearance; many people still wear traditional Kurdish cloth even when traveling to other provinces and cities (Yasemi, 1991; Kasraian \& Arshi, 1994).

\subsection{Typology of personal names in Kurdistan}

The 2346 names which were collected were classified into 10 categories, as listed below, from the most frequent to the least frequent respectively:

\subsubsection{Names associated with ethical qualities}

The most frequent names ( 654 cases $=27.88$ percent $)$ are names referring to ethical qualities. These names include both favorable names and names indicating undesirable states; less than 10 percent of the names of this category are undesirable. Virtues among people of Kurdistan are favorable and this province has never been reported to be among top crime-affected provinces announced annually by the police statistics center. 
Abbas Eslami-Rasekh, Mohammad Ahmadvand

Table 1: Names associated with ethical qualities

\begin{tabular}{||l||l||}
\hline \hline Inner Characteristics & Some Examples \\
\hline \hline favorable features & Zhibān: tactful, \\
& Dānyār: generous, \\
& Veryā: self-conscious, \\
& Delniyā: confident, \\
& Ārām: peaceful, \\
& Āzād: free, \\
& Āzerm: modesty \\
\hline \hline unpleasant states & Bāshilā: bewildered, \\
& Tenyā: lonely, \\
& Pashiyo: distressed, \\
& Pehzhāra: depressed, \\
& Mehsetoor: drunk but shy \\
\hline
\end{tabular}

\subsubsection{Names associated with nature}

The second frequent category ( 420 cases $=17.90$ percent of the names) in the ranking includes names referring to nature. These names may refer to a number of things as listed in table 2 .

Table 2: Names associated with nature

\begin{tabular}{|l|l|}
\hline Nature & Some Examples \\
\hline parts of the day & Bahyān: dawn \\
\hline rain or snow & Bafrin: snowy \\
\hline Regular happenings in nature & Āsoo: horizon \\
\hline common geographical names & Behark: lake \\
\hline seasons & Behār: spring \\
\hline $\begin{array}{l}\text { description of natural } \\
\text { processes }\end{array}$ & $\begin{array}{l}\text { Bafrow: a brook created by melting of the } \\
\text { snow }\end{array}$ \\
\hline natural objects & Rozh: the sun \\
\hline weather conditions & Bāhooz: hurricane \\
\hline generic names of animals & Mehlān: bird \\
\hline generic names of plants & Nehmām: sapling \\
\hline the sounds of nature & Ghāspah: the singing of quails \\
\hline
\end{tabular}

Kurdish names and their high frequency show that people of Kurdistan are considerably nature-oriented demonstrating their attention to locating natural events; this is also consistent with historical facts about their life style and the role that nature plays in their lives (Kasraian \& Arshi, 1994). 
4.2.3. Names referring to proper geographical locations

There are names ( 312 cases $=13.30$ percent $)$ which show name-givers' referring to various geographical places. These names may be the names of various locations as shown in table 3 .

Table 3: Names referring to proper geographical locations

\begin{tabular}{|l|l|}
\hline Proper Geographical Names & Some Examples \\
\hline cities & Mahābād, a city in Iran \\
\hline villages & Sārāl, a village in Kurdistan \\
\hline mountains & Kārookh, a mountain in Kurdistan \\
\hline plains & Ārān, a vast area in Azerbaijan \\
\hline rivers & $\begin{array}{l}\text { Ārāz, a river at the border of Iran and } \\
\text { the former Soviet Union }\end{array}$ \\
\hline
\end{tabular}

Name-giving in Kurdistan easily borrow and use proper geographical names from other countries like Iraq, Azerbaijan, Turkey, Russia, and even India; this is explainable by reference to historical facts about the migration and settlement of Aryans in different countries (Yasemi, 1991; Kasraian \& Arshi, 1994). Kurdish people constitute an important ethnic minority group in Iran, Iraq, Syria, and Turkey.

\subsubsection{Names associated with historical characters}

There are many names ( 258 cases $=11$ percent) referring to historical characters who may be real or fictional. These names show people's interest in their history, especially the glorious history of Kurdish kings, princes, and heroes. These names connect the present back to ancient Persia, especially the Mādz Dynasty, the Sassanid Dynasty, and the Aryan race.

Table 4: Names associated with historical characters

\begin{tabular}{|l|l|}
\hline Historical Characters & Some Examples \\
\hline \multicolumn{1}{|c|}{ real characters } & Nevshirvān, a real king in ancient Iran; \\
& Diyāko, the founder of the Mādz Dynasty in \\
& Iran; \\
& Ātropāt, a commander who fought against \\
& Alexander; \\
& Ātoosā, a Kurdish prince of 716 B.C.; \\
\hline fictional characters & Ābtin, the father of Freydoon in the world- \\
& known epic of Ferdowsi, i.e., "Shāhnāmeh"; \\
& Ādoo, the god of wind in Persian mythology; \\
& Ārash, the famous archer in Shāhnāmeh \\
\hline
\end{tabular}


Abbas Eslami-Rasekh, Mohammad Ahmadvand

4.2.5. Names associated with appearance and physical features

Names referring to appearance and physical features ( 234 cases $=9.98$ percent) imply only desirable physical qualities of a person's eyes, body, hair, etc. There is no name which mentions physical defects in the face or body of others.

Table 5: Names associated with appearance and physical features

\begin{tabular}{|l|l|}
\hline Physical Features & Some Examples \\
\hline positive & Chāv Javān: having beautiful eyes, \\
& Kāli: the blue-eye girl with golden hairs, \\
& Lāvchāk: good-looking, \\
& Āvātesh: beautiful and tidy, \\
& Māsa: like the moon, \\
\hline
\end{tabular}

4.2.6. Names associated with animals and plants

Under the category of nature we had generic names of animals and plants; however, special species of animals and plants (198 cases $=8.44$ percent) show interesting patterns in name-giving to the extent that a category is worth being allocated to them. The names of special flowers are only used for girls. Tulip has several equivalents in Kurdish including Goolāleh, Halāleh, and Lāleh.

The animal names used for boys are names of hunters like Shirkoo meaning mountain lion while animal names which are used for girls are domestic or nonhunter animals like Āski meaning deer. For deer or gazelle, interestingly, there are many equivalents like Āski, Āsk, Āskeh, Āskool, Khazāl, and Kazhāl.

Table 6: Names associated with animals and plants

\begin{tabular}{|l|l|}
\hline Animals and Plants & Some Examples \\
\hline plants & Behyāneh: the fruit of quince \\
& Chiman: lawn \\
& Hiro, a kind of local flower; \\
& Gelyār meaning pomegranate flower; \\
& Senobar; fir tree \\
& Nasrin meaning jonquil \\
\hline animals & ,Āāneh: royal falcon, \\
& Haloo: eagle, \\
& Ghomri, a kind of local bird similar to doves, \\
& Sāroo, a kind of local bird \\
& Shābāz, hawk \\
\hline
\end{tabular}

4.2.7. Names referring to ethnic origin

Reference to these names ( 108 cases $=4.60$ percent) shows the national and ethnic inclinations of the Kurdistan Province and their love for their homeland. In Iran, 
hence in Kurdistan, the country is called motherland, so names like Midiyā, Nishtemān, Koordestān, and Irān are specific to girls.

Table 7: Names referring to ethnic origin

\begin{tabular}{|c|c|}
\hline Names Referring to Ethnic Origin & Some Examples \\
\hline reference to the Kurdistan Province & $\begin{array}{l}\text { Koordestān which is a female name, } \\
\text { Ārdehlān, the ancient name of Kurdistan }\end{array}$ \\
\hline homeland & $\begin{array}{l}\text { Midiyā meaning the homeland of Mādz, } \\
\text { Nishtemān meaning homeland, }\end{array}$ \\
\hline race & $\begin{array}{l}\text { Āryān meaning a member of the Aryan } \\
\text { race }\end{array}$ \\
\hline historical and religious background & Ātoorbān meaning the guard of fire \\
\hline ancestors & $\overline{\mathrm{A}} \mathrm{b} \overline{\mathrm{a}}$ meaning ancestors \\
\hline tribes & $\begin{array}{l}\text { Razān which is the name of a tribe in } \\
\text { Kurdistan }\end{array}$ \\
\hline $\begin{array}{l}\text { names with symbolic values of } \\
\text { patriotism }\end{array}$ & Ālā meaning flag \\
\hline
\end{tabular}

4.2.8. Names associated with local customs and practices

These names $(108$ cases $=4.60$ percent $)$ may show:

Table 8: Names associated with local customs and practices

\begin{tabular}{|l|l|}
\hline Local Customs & Some Examples \\
\hline Life style & $\begin{array}{l}\text { Berivān: a girl who accompanies the } \\
\text { shepherd and milks the cows }\end{array}$ \\
\hline festive practices & $\begin{array}{l}\text { Choopi, a kind of dance for weddings or } \\
\text { so in which one is the leader and others } \\
\text { taking each other's hands follow the } \\
\text { rhythm of the leader }\end{array}$ \\
\hline religious or spiritual practices & $\begin{array}{l}\text { Semā' which is a special dance exercised } \\
\text { by dervishes, i.e. ascetic Muslim monks }\end{array}$ \\
\hline objects used in ceremonies & $\begin{array}{l}\text { Tārā which means a thin piece of red } \\
\text { cloth put on the head of brides }\end{array}$ \\
\hline verbal heritage & $\begin{array}{l}\text { Chirok meaning a legend or sweet story } \\
\text { retold in the Kurdish language }\end{array}$ \\
\hline musical traditions & $\begin{array}{l}\text { Shānāz, a famous melody from the } \\
\text { Sassanid Dynasty period }\end{array}$ \\
\hline traditional literary characters & $\begin{array}{l}\text { Zeyn , the name of a girl in a Kurdish } \\
\text { love poem }\end{array}$ \\
\hline
\end{tabular}




\subsubsection{Sectarian names}

Sometimes the proper names with a reference to divine or religious people are chosen for children hoping that children will acquire the good characteristics of these people, or just to show their respect for these people. These names are of three categories as shown in table 9.

Table 9: Sectarian names or religious people

\begin{tabular}{|c|c|}
\hline Sectarian Names & Some Examples \\
\hline $\begin{array}{l}\text { names of prophets, imams, and } \\
\text { their children }\end{array}$ & $\begin{array}{l}\text { Ebrāhim (Abraham), } \\
\text { Mohammad (the prophet of Islam), } \\
\text { Soleymān which is Solomon } \\
\text { Ali, the first Imam of Shi'ite Muslims } \\
\text { Aboobakr, the first Imam of Sunni Muslims }\end{array}$ \\
\hline $\begin{array}{l}\text { names of important Islamic } \\
\text { characters or leaders }\end{array}$ & $\begin{array}{l}\text { Sallāheddin (Saladin), the Sultan of Syria } \\
\text { and Egypt who conquered Jerusalem in } \\
1187 ; \\
\text { Mokhtār; a famous warrior } \\
\text { Somayyeh, one of the first women accepting } \\
\text { Islam }\end{array}$ \\
\hline $\begin{array}{l}\text { names which have affixes showing } \\
\text { people's care for religion }\end{array}$ & $\begin{array}{l}\text { Habibollāh meaning the friend of God, } \\
\text { Kamāllodin meaning the perfection of } \\
\text { religion, Yadollāh meaning the hand of God }\end{array}$ \\
\hline
\end{tabular}

\subsubsection{Miscellaneous names}

There were also some names ( 24 cases $=1.02$ percent $)$ which could not be granted any category or could not be put in any of the nine categories above (e.g. Ārvān meaning trip, Rivān meaning passer-by, Kārvān meaning caravan, or Shāroo meaning untouched).

Table 10: Miscellaneous names

\begin{tabular}{|l|l|}
\hline Miscellaneous Names & Some Examples \\
\hline different names with low frequencies & Chapek meaning group \\
& Nizām meaning soldier \\
& Hāver meaning bringer \\
& Yekbin meaning seeing like each other \\
\hline
\end{tabular}

\subsection{Trends of change in name-giving in Kurdistan}

For this part 50 Kurdistani residents were asked to write down the name of their relatives and friends. Altogether 2441 tokens were collected in this way. By investigating the names of the older generation (60 years old or older) and the younger generation (25 years old or younger) three trends of change were identified: 
4.3.1. A change from common nationwide names toward ethnic Kurdish names

This trend of change (shown in table 11) shows that people of Kurdistan Province are practicing an autonomous ethnic maintenance. Only 7.81 percent of the older generation had names with ethnic Kurdish origins; this number for younger generations increases to 23.48 percent during a 40-year period. In Kurdistan, unlike other countries previously studied, ethnic names are chosen for women more than for men. Also, this trend of change is more of a maintenance nature than segregation because there are many names which show Kurdistan people's concern for their country "Iran" as well as their province and their ethnic identity.

Table 11: Change from nationwide names toward ethnic Kurdish names

\begin{tabular}{|l|c|c|c|c|}
\hline age group & \multicolumn{2}{|c|}{ The Elderly } & \multicolumn{2}{c|}{ The Young } \\
\hline total number of names & \multicolumn{2}{|c|}{768} & \multicolumn{2}{c|}{1456} \\
\hline total umber of ethnic names & \multicolumn{2}{|c|}{60} & \multicolumn{2}{c|}{342} \\
\hline total percentage of ethnic names & \multicolumn{2}{|c|}{7.81} & \multicolumn{2}{c|}{23.48} \\
\hline gender & men & women & men & women \\
\hline number of names & 428 & 340 & 612 & 844 \\
\hline number of ethnic names & 36 & 24 & 98 & 244 \\
\hline percentage of ethnic names & 8.41 & 7.05 & 16.01 & 28.90 \\
\hline
\end{tabular}

4.3.2. A change from sectarian names towards names associated with ethical qualities

This trend of change shows people believe that determining and defining ethical qualities is more influential than just choosing the name of a person who is famous to have these virtues. The results show that, on the average, we have a decrease of 20.18 percent in the use of sectarian names by youngsters. The difference between young women and young men is not considerable. The analysis of the names shows that there is a clear decrease in the use of some Sunni religious characters such as Omar, Othmān, Aboobakr, and Āyesheh; this may be a kind of compromise with the official religion of the country which is Shi'ite Islam, especially because Shi'ite people don't have positive attitudes towards these characters.

With regards to names referring to ethical qualities, the results of the study show an increase of 1.92 percent of these names in the new generation. The growth for younger men (3.93) is more than that of younger women (0.58).

Table 12: change from sectarian or religious people's names towards names associated with ethical qualities

\begin{tabular}{|l|c|c|}
\hline age group & The Elderly & The Young \\
\hline total number of names & 768 & 1456 \\
\hline total umber of sectarian names & 204 & 93 \\
\hline total percentage of sectarian names & 26.56 & 6.38 \\
\hline
\end{tabular}


Abbas Eslami-Rasekh, Mohammad Ahmadvand

\begin{tabular}{|l|c|c|c|c|}
\hline $\begin{array}{l}\text { total number of names associated with ethical } \\
\text { qualities }\end{array}$ & \multicolumn{2}{|c|}{115} & \multicolumn{2}{c|}{246} \\
\hline $\begin{array}{l}\text { total percentage of names associated with ethical } \\
\text { qualities }\end{array}$ & \multicolumn{2}{|c|}{14.97} & \multicolumn{2}{c|}{16.89} \\
\hline gender & men & women & men & women \\
\hline number of names & 428 & 340 & 612 & 844 \\
\hline umber of sectarian names & 128 & 76 & 64 & 29 \\
\hline percentage of sectarian names & 29.90 & 22.35 & 10.45 & 3.43 \\
\hline number of names associated with ethical qualities & 65 & 50 & 117 & 129 \\
\hline percentage of names associated with ethical qualities & 15.18 & 14.70 & 19.11 & 15.28 \\
\hline
\end{tabular}

4.3.3. A change from compound or two-word names towards single names

The percentage for the use of compound or two-part names (names consisting of two separate words, or a combination of a word and an affix) shows a decrease of 8.08 percent among the young. This is more interesting when we know that this trend of change in Kurdistan is completely in contrast with the trend of change in the country based on our analysis of the statistics released by the National Organization for Civil Registration of Iran (Karami, 2011).

Regarding the difference between male and female names, it was observed that both in the names of the elderly and the young, men outnumber women (almost twice more) in using compound or two-part names. One reason for this change which is also compatible with the first trend of change is that the Kurdish language _ just like the language of American Indians_ has words with lengthy meanings which remove the need to use more words and hence names to negotiate their ideas. As some people interviewed reported one of the reasons some people use compound names is that the parents can't come to an agreement on the name of their children resulting in compound names or two separate names (one formally registered and used at school and one informally used by the family at home). The resistance of Kudistan people to use two-part names can be a reflection of their traditional families in which the man is the head and the decision-maker of the family. It may also be a kind of reluctance to give up to the fashion of the day by Kurdistan people who have shown to be concerned about their ethnic identity (Yasemi, 1991; Kasraian \& Arshi, 1994).

Table 13: A change from two-part or combination names towards one-part names

\begin{tabular}{|l|c|c|c|l|}
\hline \multicolumn{1}{|c|}{ Age group } & \multicolumn{2}{c|}{ The Elderly } & \multicolumn{2}{c|}{ The Young } \\
\hline total number of names & \multicolumn{2}{c|}{768} & \multicolumn{2}{c|}{1456} \\
\hline total umber of compound or two-part names & \multicolumn{2}{|c|}{80} & \multicolumn{2}{c|}{34} \\
\hline total percentage of compound or two-part names & \multicolumn{2}{|c|}{10.41} & \multicolumn{2}{c|}{2.33} \\
\hline gender & men & women & men & women \\
\hline number of names & 428 & 340 & 612 & 844 \\
\hline number of compound or two-part names & 56 & 24 & 20 & 14 \\
\hline percentage of compound or two-part names & 13.08 & 7.05 & 3.26 & 1.65 \\
\hline
\end{tabular}




\section{Discussion and Conclusion}

All the three hypotheses of the study gained strong support. Firstly, the name referents showed obvious effects of socio-cultural values of the people of Kurdistan; their names reflected their love of virtues, nature, their land, and their history. Also, there were many names which showed how they attended to the most delicate details of the nature and to whatever was important in their everyday life.

Secondly, we found significant male/female differences in names which referred to animals and plants, for example, the names of flowers were only used for women, and the animal names used for men were the names of hunter animals and for girls domestic or non-hunter animals. Also, all names meaning homeland were specific to girls. The difference of male/female names was also obvious in the trends of change identified in that women were given more ethnic names, women had more names associated with physical features, and that women had fewer compound or two-part names.

The third hypothesis regarding differences between the older and the younger generations was also supported by data. Young people used more ethnic names, more non-sectarian names, and fewer compound or two-part names.

Gerhards and Hans (2009) introduced four scenarios for describing changes in names: forced acculturation, forced segregation, voluntary acculturation, and voluntary segregation. We would like to add a fifth one which we call "Avoidance of Severe Segregation". Here, people avoid using special names (ethnic, sectarian, etc.) voluntarily without any force by the government or law but do not adopt the majority group names. Instead, they use other ethnic names which are not problematic. This avoidance of severe segregation was observed in Kurdistan when people based on their social experiences avoid giving the names of some Sunni characters to their children because they don't want their children to have any problem when traveling to other cities, especially Shiite cities, but instead of adopting Shiite names (the official religion of Iran) they choose their ethnic Kurdish names.

Another point which needs clarification is the trend of change from nationwide common names towards ethnic Kurdish names. This change seems to be more of a maintenance nature than segregation; this is because Kurdish young people still use many nationwide common names and names like "Irān" which is the name of the country itself is still one of the favorite names of girls. Also, people of Kurdistan easily borrow geographical names from other areas of Iran, and not just Kurdistan. It seems that people of Kurdistan are trying to define their own ethnic Kurdish identity but within the larger Iranian community. 
Abbas Eslami-Rasekh, Mohammad Ahmadvand

Another interesting point is that, unlike other studies such as Sue and Telles (2007) and Gardner (1988, 1992, 1993), the people of Kurdistan choose more ethnic names for girls. This important difference and the classification of names into different categories show that socio-cultural values of people affect naming and that these values differ from country to country; this reminds us of the very fact that understanding the cultures of people from different geographical areas or ethnic groups needs more studies of the kind we call 'intercultural studies'.

\section{Limitations of the Study and Suggestions for Further Research}

The researchers decided to collect data from various sources to ensure diversity of data and generalizability of the results. Using other sources for data collection or using only official data may yield different results. Also, we didn't consider the linguistic features of names, the combination of lexemes, the linguistic structure of names, the sound patterns in the names, the harmony they may have with other names, and people's interest of using sound-harmonious names for their children; these areas are potential areas for further research. Also, other researchers may decide to change our categories, the number of categories, or the criteria for assigning names to categories.

\section{References and notes:}

Aden, E. (2014). Naming your baby. Retrieved February 10, 2014, from http://www.babynamestats.com/

Alford, R. D. (1987). Naming and identity: A cross-cultural study of personal naming practices. New Haven, Connecticut: HRAF Press

Bloor, M. \& Bloor, T. (2007). The practice of discourse analysis. London: Hodder Arnold.

Bryner, J. (2010). Parents choosing more unusual baby names now. Retrieved February 2, 2014, from http://www.livescience.com/9841-parents-choosing-unusual-babynames.html

Conrad, L. (2010). Why giving personalized baby item are special- different culture's traditions in naming a child. Retrieved January 12, 2014, from $\mathrm{http} / / /$ EzineArticles.com/?expert=linda_conrad

Djcnonyomaye, F. (2002). Names have special meanings in many African countries. Silver International Newspaper. Retrieved October 12, 2013, from http://silverinternational.mbhs.edu/v161/v16.1.05b.africanname.htm

Encyclopedai of Children (2011). Naming. Encyclopedia of Children and Childhood in History and Society. Available online: http://www.faqs.org/childhood/MePa?Naming.html

Gardner, S. (1988). Arabic personal names: their meanings and significance. In Linguistic Circle of Manitoba \& North Dakota, 28, 15-17.

Gardner, S. (1992). Gender imbalance in Sudanese Arabic names. Paper presented at the annual meeting of the Canadian Society for the Study of Names. Charlottetown, PEI.

Gardner, S. (1993). The nature and extent of religious significance of urban male names in northern Sudan. Paper presented at the International Congress of Onomastic Sciences, Trier. 
Gardner, S. (1994). Generations of change in name-giving. In Yasir Suleiman (Ed), Arabic Sociolinguistics: Issues \& Perspectives. (PP. 101-126). Richmond: Curzon Press Ltd.

Gerhards, J. \& Hans, S. (2009). From Hasan to Herbert: Name-Giving patterns of immigrant parents between acculturation and ethnic maintenance. AJS, 114(4), 1102-28.

Ghaleb Al-Zumor, A. Q. (2009). A Socio-cultural and linguistic analysis Of Yemeni Arabic personal names. GEMA Online Journal of language Studies, 2.

Girvilas, K. A. (1978). Pre-Christian name giving in Lithania. Lithuanian Quarterly Journal of Arts and Sciences, 24(3).

Gordon, M. M. (1964). In Gerhards, T. and Hans, S. (2009). From Hasan to Herbert: Namegiving patterns of immigrant parents between acculturation and ethnic maintenance. AJS, 114(4), 1102-28.

Gurdun, K. (2002). Icelandic personal names in past and present. Onoma, 37, 293-300.

Jeshion, R. (2009). The significance of names. Mind \& Language, 24(4), 372-405.

Johnston, B. (2008). Discourse Analysis (2nd ed.). UK: Blackwell Publishing Ltd.

Karami M. (2011). Changes in name-giving [Taghir dar namgozari]. Internet Interview. Retrieved March 14, 2013, from http://www.tabnak.ir/fa/news/228035

Kasraian, N. \& Arshi, Z. (1994). Kurds of Iran. Tehran, Iran: Agah Publications.

Liberson, S. (2009). In Gerhards, T. and Hans, S. From Hasan to Herbert: Name-giving patterns of immigrant parents between acculturation and ethic maintenance. AJS, 114(4), 1102-28.

Myrand, L. E. (2011). The origin and meaning of names. Retrieved July 9, 2013, from http://www.mayrand.Org/meaning-e2.htm

Medlej, Y. (2011). Issues of naming. Retrieved June 22, 2013, from http://www. cedarseed.com/air/ namearticles2.html

Penbek, S., Yurdakul, D., \& Cerit, A. G. (2009, July). Intercultural communication competence: A study about the intercultural sensitivity of university students on their education and international experiences. Paper presented at European and Mediterranean Conference on Information Systems. Izmir

Rosenhouse, J. (2002). Personal names in Hebrew and Arabic: Modern trends compared to the past. Journal of Semetic Studies, 7(1), 97-114.

Sue, C. A. \& Telles, E. E. (2007). Assimilation and gender in naming. American Journal of Sociology, 112(5), 1383-1415.

Toppe, R. (2011). Norwegian baby names. Retrieved July 29, 2013, from http://bestnorwegian.com/norwegian_baby_names.html

Wang, Y. \& Le, T. (2006, November). Teaching, learning and management: A case study of intercultural communication and education. Paper presented at AARE 2006 Conference Proceedings, Adelaide.

Wardhaugh, R. (2006). An Introduction to Sociolinguistics (5th ed.). Uk: Balckwell Publishing Ltd.

Wikipedia, (2011). Given Name. Online: Retrieved October 11, 2011, from http:en.wikipedia.org/wiki/Namegiving

Yasemi, R. (1991). Kurd and his historical and ethnic continuity[Kord va peyvastegiye nezhadi va tarikhiye anha]. Tehran, Iran: Bonyade Moghoofate Doktor Mahmood Afshar Publications. 


\title{
Summary
}

\section{Name-giving variations in Kurdistan Province of Iran: An ethnic identity marker categorized}

\author{
Abbas Eslami-Rasekh \\ University of Isfahan, Iran \\ Mohammad Ahmadvand \\ University of Isfahan, Iran
}

Name-giving, in addition to being an act of designation or official registration, implies the cultural identity of name-givers. One obvious aspect is showing the social values and practices in an area. This study aims to explore the social factors which motivate namegiving among Kurdish ethnicity of Iran. The corpus of data for the analysis included the National Organization for Civil Registration of Iran, Kurdish websites, interviews, and questionnaires given to Kurdish citizens of Kurdistan. The important classifying variable is the socio-cultural preferences which were compared through using the frequency of different categories of names. The results of the study showed that ten categories would divide first names; the five most frequently used categories of names include: reference to ethical qualities, nature, geographical locations, ancient characters, and outer physical features respectively. Another goal of the study concerned the diachronic changes in namegiving which was carried out by comparing the most frequent names of two age groups: 60 years or older compared with the 25 years or younger. Interesting findings were uncovered which showed three trends of change among the Kurdish name-givers: a shift from common nationwide names towards ethnic Kurdish names, and sectarian to names referring to ethical qualities; additionally, a tendency was observed to move from combined name compounds to simple ones. The implications of these findings might be interpreted as name-givers' preference for not only maintaining ethnic independence but also an observable desire to display a sense of unity.

Key Words: intercultural communication, ethnicity, name-giving, values and beliefs 